\title{
Studi Penggunaan Profilaksis Stress Ulcer pada Pasien Bedah Digestif di RSUD dr. Soetomo Surabaya
}

\author{
Indira Dayang Mahdayana ${ }^{1 *}$, Sudjatmiko ${ }^{1}$, Sumarno $^{2}$, Elfri Padolo $^{3}$ \\ ${ }^{1 *}$ Program Studi Magister Farmasi Klinis, Fakultas Farmasi Universitas Airlangga, Surabaya, Indonesia, ${ }^{1}$ Divisi Bedah \\ Digestif, SMF Ilmu Bedah, Fakultas Kedokteran Universitas Airlangga, RSUD dr.Soetomo, Surabaya, Indonesia, \\ ${ }^{2}$ Departemen Farmasi Klinis, Fakultas Farmasi Universitas Airlangga, Surabaya, Indonesia, ${ }^{3}$ Instalasi Farmasi RSUD \\ dr.Soetomo, Surabaya, Indonesia
}

\section{INFO ARTIKEL}

Sejarah artikel:

Penerimaan naskah: 7 Januari 2020

Penerimaan naskah revisi: 18 Februari 2020 Disetujui untuk dipublikasikan: 2 April 2020

\section{Kata kunci :}

Stress ulcer, profilaksis, bedah digestif, omeprazol, ranitidin

\section{A B S TRAK}

Profilaksis stress ulcer seringkali disertai dengan penggunaan yang tidak tepat indikasi dan berlebihan pada pasien non-critically ill atau hospitalized patients. Hal ini dapat berdampak pada peningkatan biaya pengobatan, potensi interaksi obat, efek samping dan lama rawat pasien di rumah sakit. Studi ini dilaksanakan dengan metode retrospektif dari data rekam medik kesehatan periode 1 Januari - 31 Desember 2015 di RSUD dr. Soetomo, Surabaya, Jawa Timur dengan tujuan untuk mengetahui pola penggunaan profilaksis stress ulcer, khususnya pada pasien bedah digestif. Sejumlah 40 pasien memenuhi kriteria inklusi. Hasil dari kajian ini menunjukkan bahwa profilaksis diberikan dengan frekuensi $1-3 \mathrm{kali} / \mathrm{hari}$ baik secara tunggal atau kombinasi dengan rute per oral maupun intravena. Pemberian profilaksis stress ulcer tunggal pada pasien bedah digestif yang terbesar adalah ranitidin $(83,9 \%)$. Sedangkan untuk pemberian kombinasi, yang paling banyak diberikan adalah antagonis $\mathrm{H}_{2}-\mathrm{PPI}$ $(62,5 \%)$. Durasi pemberian profilaksis stress ulcer pada hospitalized pasien didasarkan pada kondisi klinis pasien, yaitu mual dan muntah.

\section{Drug Utilization Study of Stress Ulcer Prophylaxis in Digestive Surgery Patient at dr. Soetomo General Hospital Surabaya}

\section{Keywords:}

Stress ulcer; prophylaxis; digestive surgery; omeprazole; ranitidine

\begin{abstract}
A B S T R A C T
Stress ulcer prophylaxis is often accompanied by inappropriate and excessive use in non-critically ill or hospitalized patients. This could have an impact on increasing treatment costs, potential drug interactions, side effects, and length of stay patients in the hospital. This study was conducted using a retrospective method of health medical record data for the period of $1^{\text {st }}$ January $-31^{\text {st }}$ December 2015 at RSUD dr. Soetomo, Surabaya, East Java to determine the pattern of the use of prophylactic stress ulcers, especially in digestive surgery patients. Fourty patients met the inclusion criteria. The results of this study indicate that prophylaxis is given at a frequency of 1-3 times/day either single or in combination with an oral route or intravenously. Ranitidine is the most used stress ulcer prophylactic (83.9\%). As for the combination, the most widely used is the $\mathrm{H}_{2}$ antagonist-PPI $(62.5 \%)$.
\end{abstract}




\section{Pendahuluan}

Stress ulcer (SU) merupakan erosi dari mukosa duodenal atau ulcer yang umumnya diinduksi oleh trauma serius seperti operasi, luka bakar yang luas, benturan pada kepala, komplikasi pada beberapa organ seperti ginjal, paru-paru, hati, dan lain-lain. ${ }^{1,2}$

Terdapat beberapa faktor yang dapat menyebabkan $\mathrm{SU}$, termasuk sekresi asam lambung berlebih dan iskemia mukosa lambung (akibat hipoperfusi splachnic). Hipoperfusi dapat menyebabkan ketidakseimbangan antara pasokan dan kebutuhan oksigen sehingga dapat menginduksi kerusakan mukosa. Akibat ketidakseimbangan tersebut, memicu terjadinya iskemia yang mana kemampuan mukosa untuk menetralisasi ion hidrogen menurun dan menyebabkan kematian sel yang kemudian menginduksi timbulnya ulcer. $^{3}$

Perdarahan saluran cerna bagian atas dapat diklasifikasikan menjadi variceal atau nonvariceal bleeding. Nonvariceal bleeding dibagi lagi menjadi Peptic Ulcer Disease (PUD) dan Stress Related Mucosal Disease (SRMD) (stress gastritis, stress ulcer, atau stress erosions), kedua nya merupakan komplikasi yang disebabkan dari asam lambung. ${ }^{4}$ Penampakan dan patofisiologi dari dua kondisi ini berbeda, perdarahan pada PUD muncul sebelum pasien masuk rumah sakit (RS), sedangkan perdarahan pada SRMD biasanya muncul saat pasien sedang menjalani perawatan di rumah sakit atau merupakan komplikasi dari penyakit yang dideritanya. Selain itu, etiologi utama dari PUD adalah infeksi $H$. pylori dan penggunaan NSAID. Sedangkan etiologi dari SRMD adalah iskemi pada mukosa sehingga menyebabkan aliran darah ke lambung menurun. Lesi pada SRMD biasanya tanpa gejala, lebih dari satu dan muncul pada proksimal lambung. ${ }^{2,5}$

Guideline yang dipublikasikan oleh American Society of Health-System Pharmacists (ASHP) merekomendasikan profilaksis stress ulcer hanya dapat digunakan pada pasien ICU dengan sedikitnya satu faktor risiko yang muncul. Sampai saat ini, belum terdapat guideline pemberian profilaksis stress ulcer untuk pasien non ICU dan pemberiannya masih berdasar intuisi klinisi dan belum berdasar evidence based. Faktor risiko yang juga terdapat pada sampel penelitian ini adalah tindakan pembedahan. Pasien yang akan menjalani pembedahan pasti akan mengalami kecemasan dan rasa takut terhadap penyuntikan, nyeri, luka, anestesi dan bahkan kemungkinan cacat atau mati. Kondisi tersebut akan merangsang dilepaskannya norepinefrin, serotonin dan histamin. Mediator histamin merupakan perangsang sekresi asam lambung dan pepsin, sehingga jika terjadi pelepasan histamin yang berlebih dapat memicu terjadinya ulkus. ${ }^{6}$ Selain itu, selama operasi berlangsung, pasien berada dalam kondisi dibawah anestesi. Obat dan teknik anestesi pada umumnya dapat mengganggu fungsi pernafasan, sirkulasi vaskular dan sistem saraf. Gangguan pernafasan dapat menyebabkan hipoventilasi dan hipoksia jaringan, sedangkan gangguan sirkulasi dapat menyebabkan hipoperfusi jaringan. Akibat dari kondisi hipoventilasi dan hipoperfusi tersebut, nutrisi dan oksigen yang dibutuhkan untuk mempertahankan integritas dan regenerasi sel mukosa tidap tercukupi sehingga dapat terjadi penurunan integritas mukosa dan dapat mengakibatkan penurunan kemampuan regenerasi sel mukosa bahkan kematian sel. ${ }^{6,7}$

Terdapat penelitian menyatakan bahwa kebanyakan pemberian profilaksis stress ulcer pada pasien noncritically ill atau hospitalized di rumah sakit tanpa adanya indikasi yang tepat. Sebanyak $79 \%$ pasien menerima profilaksis stress ulcer padahal tidak terdapat faktor risiko pada pasien. Hasil ini sama dengan pengamatan oleh Nasser et.al, dimana hanya $17 \%$ dari non-critically ill pasien yang menerima PPI intravena dengan indikasi yang tepat. $^{3,8}$

Terapi yang paling banyak digunakan dalam profilaksis stress ulcer adalah acid suppressive therapy (AST) diantaranya adalah golongan Proton Pump Inhibitor (PPI) dan antagonis $\mathrm{H}_{2}$. Beberapa penelitian menyatakan bahwa AST digunakan secara berlebihan pada pasien noncritically ill atau hospitalized patient. Hal ini, dapat menyebabkan peningkatan biaya pengobatan, peningkatan kemungkinan interaksi obat, peningkatan efek samping, dan berpotensi meningkatkan risiko pneumonia atau infeksi Clostridium difficile. ${ }^{6,9}$

Oleh karena banyaknya problematika yang muncul pada pemberian profilaksis stress ulcer pada hospitalized patient dan salah satunya adalah pasien kasus bedah digestif, maka tujuan penelitian ini adalah mengetahui pola penggunaan profilaksis stress ulcer terkait jenis, dosis, rute pemberian, lama pemberian dan regimentasi dosis profilaksis stress ulcer. Hasil penelitian ini diharapkan dapat memberikan informasi tentang pola pemberian profilaksis stress ulcer bagi praktisi medis baik klinisi maupun instalasi farmasi agar dapat membantu meningkatkan mutu pelayanan pasien.

\section{Metode}

Metode penelitian yang digunakan pada penelitian ini adalah metode observasional dan pengambilan data dilakukan secara retrospektif dengan melihat rekam medik pasien. Instrumen penelitian yang digunakan adalah lembar pengumpul data (LPD). Pengambilan sampel dilakukan dengan metode time limited sampling, yaitu sampel diambil dalam periode waktu tertentu. Pada penelitian ini sampel diambil pada periode 1 Januari - 31 Desember 2015 di RSUD dr. Soetomo. Sampel meliputi semua pasien bedah digestif yang memenuhi kriteria inklusi.

Kriteria inklusi penelitian ini meliputi pasien kolelitiasis yang mengalami pembedahan, mendapatkan profilaksis stress ulcer selama rawat inap. Kriteria eksklusi penelitian ini adalah pasien yang mengalami nyeri epigastrik, sedang atau mempunyai riwayat perdarahan saluran cerna, gastroesophageal reflux disease (GERD), peptic ulcer atau erosive esophagitis, menggunakan non steroidal anti-inflammatory drugs (NSAID) sebelum atau saat rawat inap.

Tahapan penelitian yang dilakukan adalah: (1) Mendaftarkan penelitian pada bagian pendidikan dan pelatihan di RSUD dr. Soetomo untuk mendapatkan surat laik etik; (2) Memperoleh akses rekam medik kesehatan (RMK) pasien; (3) Mengumpulkan dan mencatat data 
RMK ke LPD; (4) Melakukan rekapitulasi dan pengolahan data; (5) Melakukan analisis data dan menyusun pembahasan mengenai profil penggunaan profilaksis stress ulcer. Analisis data dilakukan secara deskriptif mulai dari demografi pasien, pola penggunaan profilaksis stress ulcer yang meliputi jenis, dosis, rute pemberian, lama pemberian dan regimentasi dosis yang diberikan.

\section{Hasil dan Diskusi}

Penelitian ini telah dinyatakan lik etik oleh Komisi Etik Penelitian Kesehatan RSUD dr. Soetomo berdasarkan surat kelaikan etik No. 159/Panke.KKE/II/2016. Pada penelitian ini didapatkan 40 pasien rawat inap yang mendapatkan profilaksis stress ulcer selama periode 1 Januari 2015 - 31 Desember 2015 di RSUD dr. Soetomo.

\subsection{Data Demografi Pasien}

Dari 40 pasien yang memenuhi kriteria inklusi, diperoleh pasien laki-laki sebanyak 13 pasien $(32,5 \%)$ dan pasien perempuan sebanyak 27 pasien $(67,5 \%)$. Distribusi usia pasien terbanyak adalah 46 - 65 tahun yang merupakan kelompok usia lanjut usia (lansia) sebanyak 21 pasien.

Terdapat beberapa faktor risiko dari terbentuknya batu empedu, salah satunya adalah jenis kelamin dan umur. Perempuan memiliki risiko lebih besar, hampir dua kali lipat untuk terbentuknya gallstone atau batu empedu. Kadar estrogen yang meningkat dalam tubuh dapat meningkatkan kadar kolestrol dalam empedu dan menurunkan kontraksi kandung empedu. Peningkatan produksi estrogen dapat terjadi saat wanita mengalami kehamilan, terapi penggantian hormon estrogen untuk wanita menopause atau penggunaan pil KB. ${ }^{10}$ Kemudian faktor risiko lainnya adalah usia. Usia merupakan faktor risiko utama dari terbentuknya batu empedu. Prevalensi batu empedu sangat jarang terjadi pada anak-anak dan dapat meningkat pada usia yang lebih tua. Prevalensi paling banyak terjadi pada usia diatas 40 tahun atau usia dewasa. Hal ini karena sekresi kolestrol dalam empedu meningkat seiring dengan bertambahnya usia dan terjadi penurunan pembentukan asam empedu. Akibatnya, lemak dari makanan tidak dapat tercerna dengan baik sehingga meningkatkan risiko terbentuknya batu empedu. ${ }^{1,10}$

\subsection{Profilaksis Stress Ulcer Tunggal pada Pasien Bedah Digestif}

Tabel 1 menunjukkan distribusi pemberian profilaksis stress ulcer tunggal pada pasien bedah digestif di RSUD dr. Soetomo. Golongan antagonis $\mathrm{H} 2$, yaitu ranitidin paling banyak diberikan dengan persentase $83,9 \%$, sedangkan golongan PPI hanya sebesar 16,1\%.

Tabel 1. Distribusi Profilaksis Stress Ulcer Tunggal pada Pasien Bedah Digestif

\begin{tabular}{cccc}
\hline No & Nama Obat & Jumlah Pasien & Persentase (\%) \\
\hline 1. & Antagonis $\mathrm{H}_{2}$ & 26 & $83,9 \%$ \\
\hline 2. & PPI & 5 & $16,1 \%$ \\
\hline & Jumlah & 31 & 100 \\
\hline
\end{tabular}

Pada pasien tanpa nasogastric tube pemberian profilaksis golongan antagonis $\mathrm{H}_{2}$ lebih disarankan daripada golongan PPI intravena dengan tujuan untuk meningkatkan efektivitas terapi dan menurunkan biaya terapi. ${ }^{11}$ Golongan antagonis $\mathrm{H}_{2}$ yang digunakan pasien adalah ranitidin, hal ini disebabkan karena ranitidin jika dibandingkan dengan obat-obat golongan antagonis $\mathrm{H}_{2}$ lainnya mempunyai efek samping dan interaksi dengan obat-obat lain yang lebih sedikit jika dibandingkan dengan golongan antagonis $\mathrm{H}_{2}$ yang lain. ${ }^{2,5}$ Selain itu, mula kerja ranitidin juga lebih cepat jika dibandingkan dengan PPI, yaitu 30 menit dengan lama kerja 10 jam. Selain itu antagonis $\mathrm{H}_{2}$ juga terbukti jarang menyebabkan terjadinya infeksi nosokomial terutama pneumonia. ${ }^{2,12}$

Obat berikutnya yang banyak digunakan adalah golongan PPI yaitu sebesar 16,1\%. Golongan PPI juga merupakan agen antisekretori asam lambung seperti antagonis $\mathrm{H}_{2}$. Omeprazol dapat menjadi pilihan yang baik untuk mencegah perdarahan pada saluran cerna karena omeprazol lebih efektif dalam menghambat sekresi asam lambung (6-10 kali lebih efektif) jika dibandingkan dengan ranitidin. ${ }^{5,13}$ Namun, pada awal pemberian terapi tidak semua proton pump dinonaktifkan oleh PPI (hanya $30 \%$ ) akibatnya terjadi penundaan dalam mencapai efek penghambatan asam lambung yang maksimal. Oleh karena itu, untuk mencapai penghambatan asam lambung yang optimal diperlukan waktu sekitar $3-4$ hari sampai semua proton pump dihambat oleh PPI. Efek hambatan tersebut akan bersifat ireversibel dan bertahan sampai 36 - 96 jam, sehingga pemberian omeprazol dalam jangka panjang tidak akan berdampak signifikan pada penurunan sekresi asam lambung sampai terbentuk kembali pompa proton yang baru. Kemudian risiko terjadinya rebound gastric acid pada pemakaian jangka panjang dapat meningkatkan risiko terjadinya stress ulcer. ${ }^{12,14,15}$

Pada beberapa penelitian disebutkan bahwa di beberapa institusi kesehatan PPI merupakan AST yang paling sering digunakan bahkan di beberapa rumah sakit digunakan sebagai lini pertama untuk profilaksis stress ulcer pada pasien critically maupun non critically ill. ${ }^{16,17}$ Namun, penghambatan omeprazol terhadap sekresi asam lambung yang cukup besar dapat memicu terjadinya kolonisasi bakteri pada laring, esofagus dan paru-paru. Akibatnya, dapat terjadi peningkatan risiko pneumonia. ${ }^{13}$ Dari segi efektivitas, omeprazol oral maupun intravena sama efektifnya dalam menghambat sekresi asam lambung. ${ }^{18}$ Hal ini dapat dilihat dari lama kerja dan waktu paruh keduanya memiliki perbedaan yang tidak terlalu signifikan. ${ }^{19}$

\subsection{Profilaksis Stress Ulcer Kombinasi pada Pasien Bedah Digestif}

Profil pemberian profilaksis stress ulcer kombinasi dapat dilihat pada tabel 2. Kombinasi antara antagonis H2 dengan PPI menjadi kombinasi profilaksis stress ulcer yang paling sering digunakan dengan persentase sebesar $62,5 \%$ (5 pasien), kemudian diikuti dengan kombinasi antara antagonis $\mathrm{H}_{2}$-PPI-Sukralfat dengan persentase 
$37,5 \%$ (3 pasien).

Tabel 2. Distribusi Profilaksis Stress Ulcer Kombinasi pada Pasien Bedah Digestif

\begin{tabular}{rlcc}
\hline No & Nama Obat & $\begin{array}{c}\text { Jumlah } \\
\text { Pasien }\end{array}$ & Persentase (\%) \\
\hline 1. & $\begin{array}{l}\text { Antagonis } \\
\mathrm{H}_{2}+\text { PPI+Sukralfat }\end{array}$ & 3 & $37,5 \%$ \\
\hline 2. & Antagonis $\mathrm{H}_{2}+\mathrm{PPI}$ & 5 & $62,5 \%$ \\
\hline Jumlah & 8 & 100 \\
\hline
\end{tabular}

Pada penelitian ini kombinasi profilaksis stress ulcer diberikan pada pasien yang mengalami frekuensi mual dan muntah yang tinggi selama perawatan. Oleh karena itu, pemberian kombinasi dapat dilakukan karena pemberian profilaksis stress ulcer tunggal kurang adekuat pada 8 pasien tersebut. Kombinasi antagonis $\mathrm{H}_{2}$ pada PPI juga direkomendasikan untuk menurunkan risiko terjadinya nocturnal acid breakthrough. Selain itu, komplikasi yang dapat terjadi pada frekuensi muntah yang tinggi pada pasien adalah esofagitis. Hal ini dapat terjadi karena komposisi dari enzim-enzim dan asam lambung bersifat iritatif terhadap mukosa esofagus ${ }^{2}$, sehingga diharapkan kombinasi dari profilaksis stress ulcer dapat meningkatkan efektivitas pencegahan terjadinya stress ulcer.

\subsection{Rute Pemberian Profilaksis Stress Ulcer pada Pasien Bedah Digestif}

Pemberian profilaksis stress ulcer di RS Dr. Soetomo Surabaya paling banyak adalah ranitidin dengan pemberian melalui rute intravena. Diketahui ranitidin rute intravena lebih efektif jika dibandingkan dengan ranitidin per oral dalam penghambatan asam. Hal ini terkait dengan mula kerja dari ranitidin intravena yang jauh lebih pendek daripada ranitidin per oral yaitu $<15$ menit untuk ranitidin intravena dan $2-3$ jam untuk ranitidin per oral. ${ }^{20}$ Selain itu, ranitidin intravena mempunyai bioavailabilitas yang lebih baik. Hal ini tentu saja menguntungkan bagi pasien karena pasien membutuhkan waktu yang cepat untuk mengatasi gejala-gejala stress ulcer. ${ }^{5,20}$

Tabel 3. Distribusi Rute Pemberian Profilaksis Stress Ulcer pada Pasien Bedah Digestif

\begin{tabular}{|c|c|c|c|c|}
\hline Golongan & Nama Obat & $\begin{array}{c}\text { Rute } \\
\text { pemberian }\end{array}$ & $\begin{array}{l}\text { Jumlah } \\
\text { Pasien }\end{array}$ & $\begin{array}{c}\text { Persentase } \\
(\%)\end{array}$ \\
\hline \multirow{2}{*}{$\begin{array}{c}\text { Antagonis } \\
\mathrm{H} 2\end{array}$} & \multirow{2}{*}{ Ranitidin } & Intravena & 34 & $54,0 \%$ \\
\hline & & Per oral & 5 & $7,9 \%$ \\
\hline \multirow[t]{3}{*}{ PPI } & \multirow[t]{2}{*}{ Omeprazol } & Intravena & 13 & $20,6 \%$ \\
\hline & & Per oral & 2 & $3,2 \%$ \\
\hline & Lansoprazol & Per oral & 1 & $1,6 \%$ \\
\hline Sukralfat & Sukralfat & Per oral & 8 & $12,7 \%$ \\
\hline \multicolumn{3}{|c|}{ Jumlah Penggunaan } & 63 & 100 \\
\hline \multicolumn{5}{|c|}{$\begin{array}{l}\text { Keterangan: } \\
\text { - Persentase dihitung dari jumlah keseluruhan penggunaan obat } \\
\text { - Satu pasien dapat diberikan lebih dari satu macam rute profilaksis } \\
\text { stress ulcer }\end{array}$} \\
\hline
\end{tabular}

Pasien dengan batu kandung empedu sering mengeluh mengalami mual dan muntah pada perut bagian kanan hingga ulu hati sehingga tidak bisa menggunakan obat secara per oral. Apabila pasien sudah bisa makan dan menerima terapi secara oral, maka segera dapat dilakukan penggantian terapi intravena dengan terapi oral. Selain itu, pasien yang akan dilakukan pembedahan biasanya akan dipuasakan sehingga pemberian per oral tidak mungkin dilakukan. ${ }^{4,14}$

\subsection{Lama Pemberian Profilaksis Stress Ulcer pada Pasien Bedah Digestif}

Distribusi rentang lama pemberian profilaksis stress ulcer dipaparkan dalam tabel 4. Omeprazol diberikan dengan rentang $1-18$ hari pada 13 pasien, lansoprazol diberikan selama 2 hari pada 1 pasien, sedangkan sukralfat diberikan dengan rentang waktu 1 - 23 hari pada 23 pasien, dan ranitidin diberikan dengan rentang waktu $1-14$ hari pada 32 pasien. Sampai saat ini, belum ada guideline yang secara jelas menyatakan pemberian profilaksis stress ulcer kapan harus dimulai dan dihentikan. Namun terdapat beberapa literatur menyatakan bahwa pemberian profilaksis stress ulcer dapat dimulai pada hospitalized patient ketika terdapat minimal 2 faktor risiko dan pemberian profilaksis stress ulcer dapat dihentikan ketika salah satu atau kedua faktor risiko tersebut sudah dapat diatasi, hal ini berbeda-beda tergantung kondisi klinis pasien. ${ }^{6,8,21}$

Tabel 4. Distribusi Lama Pemberian Profilaksis Stress Ulcer pada Pasien Bedah Digestif

\begin{tabular}{ccc}
\hline Nama Obat & Lama Pemberian (Hari) & Jumlah Pasien \\
\hline Ranitidin & $1-14$ hari & 32 \\
\hline Omeprazol & $1-18$ hari & 13 \\
\hline Lansoprazol & 2 hari & 1 \\
\hline Sukralfat & $1-23$ hari & 23
\end{tabular}

Keterangan: Satu pasien dapat diberikan lebih dari satu macam rute profilaksis stress ulcer selama perawatan

\subsection{Dosis Penggunaan Profilaksis Stress Ulcer pada Pasien Bedah Digestif}

Pada tabel 5 ditampilkan kesesuaian dosis profilaksis stress ulcer yang diberikan kepada pasien batu kandung empedu. Analisis kesesuaian dosis dilakukan dengan membandingkan dosis profilaksis stress ulcer yang diberikan kepada pasien dengan pustaka yang ada. Berdasarkan guideline dari American Society of HealthSystem Pharmacists (ASHP), dosis ranitidin untuk profilaksis stress ulcer adalah $50 \mathrm{mg}$ setiap 6-12 jam secara intravena dan $150 \mathrm{mg} 2 \mathrm{x} /$ hari secara per oral. Dosis sukralfat sebanyak $1 \mathrm{~g}$ diberikan $4 \mathrm{x} /$ hari secara per oral pada saat perut kosong atau secara naso gastric dengan dosis maksimal per hari adalah $8 \mathrm{~g}$. Omeprazol dapat diberikan $60 \mathrm{mg}$ sebagai dosis muatan, kemudian dilanjutkan dengan pemberian dosis penjagaan sebanyak 20-40 mg per hari per oral atau lewat naso gastric. $5,19,22$

Pada penelitian ini, frekuensi pemberian omeprazol intravena adalah $1 \times 40 \mathrm{mg}$ dan $2 \times 40 \mathrm{mg}$ sedangkan untuk omeprazol per oral adalah $2 \times 20 \mathrm{mg}$ dan $3 \times 20 \mathrm{mg}$. Dosis 
pemberian sehari untuk omeprazol adalah sebesar 20-

$40 \mathrm{mg}$. Pada keadaan hipersekresi asam lambung dosis omeprazol dapat ditingkatkan dengan dosis muatan sebesar $60 \mathrm{mg}$ dan dosis maksimal untuk omeprazol per hari adalah sebesar $360 \mathrm{mg}$. Hal ini berarti, dosis pemberian omeprazol sudah sesuai dengan pustaka. Sedangkan untuk frekuensi pemberian Insoprazol secara per oral adalah 1x30 mg dan dapat dikatakan pemberian lansoprazol sudah sesuai dengan dosis pada pustaka. 5,19,22

Tabel 5. Profil Dosis Penggunaan Profilaksis Stress Ulcer pada Pasien Bedah Digestif

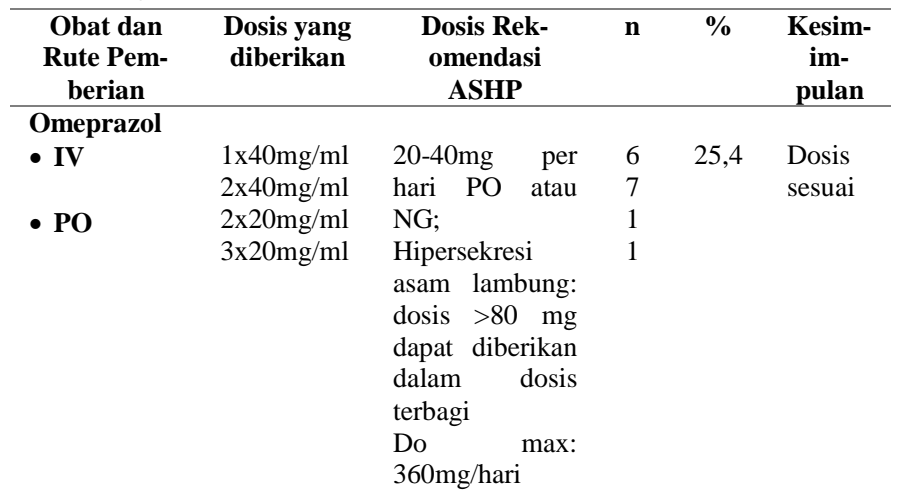

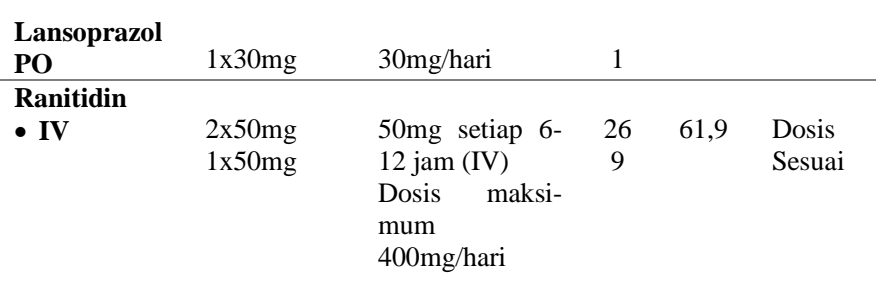

\begin{tabular}{|c|c|c|c|c|c|}
\hline - $\mathbf{P O}$ & $\begin{array}{l}3 \times 150 \mathrm{mg} \\
2 \times 150 \mathrm{mg}\end{array}$ & $\begin{array}{l}150 \mathrm{mg} 2 \mathrm{x} / \text { hari } \\
(\mathrm{PO})\end{array}$ & $\begin{array}{l}2 \\
2\end{array}$ & & \\
\hline $\begin{array}{l}\text { Sukralfat } \\
\text { - PO }\end{array}$ & $\begin{array}{l}3 \times 1 \mathrm{~g} / 10 \mathrm{ml} \\
3 \times 1.5 \mathrm{~g} / 15 \\
\mathrm{~m} 1 \\
3 \times 3 \mathrm{~g} / 30 \mathrm{ml} \\
4 \times 1.5 \mathrm{~g} / 15 \\
\mathrm{ml} \\
4 \times 3 \mathrm{~g} / 30 \mathrm{ml}\end{array}$ & $\begin{array}{l}1 \mathrm{~g}, 4 \mathrm{x} \text { per hari } \\
\mathrm{PO} \text { (pada saat } \\
\text { perut kosong) } \\
\text { atau NG } \\
\text { Dosis maksi- } \\
\text { mum, } 8 \mathrm{~g} / \text { hari }\end{array}$ & $\begin{array}{l}1 \\
2 \\
1 \\
1 \\
3\end{array}$ & 12,7 & $\begin{array}{l}\text { Terdap } \\
\text { at dosis } \\
\text { yang } \\
\text { tidak } \\
\text { sesuai }\end{array}$ \\
\hline
\end{tabular}

\footnotetext{
Keterangan:

- Satu pasien dapat diberikan lebih dari satu macam rute profilaksis stress ulcer selama perawatan

- Persentase dihitung dari jumlah keseluruhan penggunaan tiap obat
}

Pada pasien batu kandung empedu, profilaksis ranitidin secara intravena lebih banyak diberikan dengan frekuensi 2 kali dalam sehari yaitu sebanyak 26 pasien, sedangkan pemberian dengan frekuensi 1 kali dalam sehari hanya sebanyak 9 pasien. Perbedaan regimentasi dosis ini dikarenakan kondisi klinik pasien yang berbeda-beda, terutama gejala munculnya stress ulcer yaitu mual dan muntah. Rekomendasi dosis ranitidin sebagai profilaksis stress ulcer berdasarkan literatur adalah $50 \mathrm{mg}$ setiap 6-12 jam secara intravena. ${ }^{2,5,8}$ Pemberian ranitidin sebagai profilaksis stress ulcer pada penelitian ini sudah sesuai dengan rekomendasi literatur.
Pada penelitian ini pasien juga diberikan sukralfat. Mekanisme kerja dari sukralfat adalah melindungi mukosa lambung dengan membentuk lapisan pada mukosa agar tidak dirusak oleh faktor-faktor agresif lambung terutama asam lambung. Berdasar literatur ASHP, dosis pemberian sukralfat adalah $1 \mathrm{~g}, 4 \mathrm{x} /$ hari secara per oral pada saat perut kosong atau lewat naso gastric. Frekuensi pemberian sukralfat dalam penelitian ini adalah sebanyak 3x1 g/10 ml, $3 \times 1,5 \mathrm{~g} / 15 \mathrm{ml}, 3 \times 3 \mathrm{~g} / 30 \mathrm{ml}, 4 \times 1,5 \mathrm{~g} / 15 \mathrm{ml}, 4 \times 3 \mathrm{~g} / 30 \mathrm{ml}$ dengan dosis masing-masing $500 \mathrm{mg} / 5 \mathrm{ml}$. Dosis penggunaan sukralfat pada tiap pasien berbeda-beda, hal ini berdasar pertimbangan jenis penyakit dan tingkat keparahan kondisi pasien. Dosis maksimal pemberian sukralfat per hari sebesar $8 \mathrm{~g}$, sehingga dapat dikatakan terjadi ketidaksesuaian (overdosis) dalam pemberian sukralfat pada pasien dengan frekuensi pemberian $4 \times 1,5$ $\mathrm{g} / 15 \mathrm{ml}$. Pada pasien ini pemberian sukralfat per hari sebesar $12 \mathrm{~g}$ dan pada pasien dengan frekuensi pemberian $3 \times 3 \mathrm{~g} / 30 \mathrm{ml}$. Hal ini tentu perlu diwaspadai terutama pada pasien dengan gagal ginjal. Penurunan fungsi ekskresi pada pasien gagal ginjal dapat menyebabkan akumulasi aluminium. Hal ini dapat meningkatkan risiko munculnya efek samping. ${ }^{22}$

Berdasarkan hasil penelitian, profilaksis stress ulcer yang paling banyak digunakan pada pasien bedah digestif dengan diagnosis kolelitiasis di RSUD dr. Soetomo Surabaya pada periode 1 Januari - 31 Desember 2015 adalah ranitidin intravena $(62 \%)$ dengan jenis profilaksis yang diberikan adalah antagonis $\mathrm{H}_{2}$ (ranitidin), PPI (omeprazole dan lansoprazol) dan sukralfat. Profilaksis dapat diberikan tunggal maupun kombinasi dengan frekuensi $1-3 \mathrm{kali} / \mathrm{hari}$. Dosis profilaksis stress ulcer yang diberikan pada sampel penelitian sudah sesuai dengan rekomendasi guideline.

\section{Daftar Pustaka}

1. Tham TCK, Collins JS., Soetikno R. Gastrointestinal Emergencies Third Edition. Third Edit. Blackwell Publishing; 2016. 276-277 p.

2. Ganet-Schoeller M, Ducamp M. Gastrointestinal Disorder. In: Dipiro J, Schwinghammer T, editors. Pharmacotherapy Handbook. 9th ed. Mc Graw Hill; 2015. p. 251.

3. Plummer MP, Blaser AR, Deane A. Stress Ulceration: Prevalence, Pathology and Association with Adverse Outcomes. 2014;18(213):1-7. Available from: papers2://publication/uuid/47271145-D3EF-497D9FE2-2CCF86975FD6

4. Singh H, Houy TL, Singh N, Sekhon S. Gastrointestinal prophylaxis in critically ill patients. Crit Care Nurs Q. 2008;31(4):291-301.

5. Cunningham FG, Leveno KJ, Bloom SL, Spong CY, Dashe JS, Hoffman BL, et al. Drugs Affecting Gastrointestinal Function. In: Brunton L, editor. Goodman \& Gillman's the Pharmacological Basis of Therapeutics. 12th ed. Mc Graw Hill; 2014. p. 1037.

6. Guillamondegui OD, Gunter OLJ, Bonadies J a, Coates JE, Kurek SJ, De Moya M a, et al. Practice management guidelines for stress ulcer prophylaxis. 
East Assoc Surg Trauma [Internet]. 2008;1-24. Available from: http://www.east.org/resources/treatment-guidelines/

7. Spirt M, Stanley S. Update on Stress Ulcer Prophylaxis in Critically Ill Patients. Crit Care Nurse. 2006;26(1):18-28.

8. Mohamad MS, Shamsuddin N, Tan KM. Appropriateness of stress ulcer prophylaxis among older adults admitted to general medical wards in a university hospital. Eur Geriatr Med [Internet]. 2015;6(2):119-23. Available from: http://dx.doi.org/10.1016/j.eurger.2014.11.004

9. Malhis A, Alghamdi T, Alfandi R, Issa Z, Alanazi H, Alfintoukh $\mathrm{H}$, et al. Appropriateness of acidsuppressing agents for stress ulcer prophylaxis in nonintensive care unit setting in Saudi Arabia. J Pharm Bioall Sci. 2019;11(1):96-101.

10. Pitchumoni CS, Dharmarajan TS. Geriatric gastroenterology. In: Pitchumoni CS, editor. Geriatric Gastroenterology. First Edit. Springer; 2012. p. 4217.

11. Hong MT, Monye LC, Seifert CF. Acid Suppressive Therapy for Stress Ulcer Prophylaxis in Noncritically Ill Patients. Ann Pharmacother. 2015;49(9):1004-8.

12. McRorie JW, Kirby JA, Miner PB. Histamine 2 receptor antagonists: Rapid development of tachyphylaxis with repeat dosing . World J Gastrointest Pharmacol Ther. 2014;5(2):57.

13. Fohl AL. Proton pump inhibitor-associated pneumonia: Not a breath of fresh air after all? World $\mathrm{J}$ Gastrointest Pharmacol Ther. 2011;2(3):17.

14. Alhazzani W, Alshamsi F, Belley-Cote E, HeelsAnsdell D, Brignardello-Petersen R, Alquraini M, et al. Efficacy and safety of stress ulcer prophylaxis in critically ill patients: a network meta-analysis of randomized trials. Intensive Care Med [Internet]. 2018;44(1):1-11. Available from: https://doi.org/10.1007/s00134-017-5005-8

15. Shin JM, Kim N. Pharmacokinetics and pharmacodynamics of the proton pump inhibitors. $\mathbf{J}$ Neurogastroenterol Motil. 2013;19(1):25-35.

16. Alsultan M, Mayet A, Malhani A, Alshaikh M. Pattern of intravenous proton pump inhibitors use in ICU and Non-ICU setting: A prospective observational study. Saudi J Gastroenterol. 2010;16(4):275-9.

17. Barletta JF, Kanji S, MacLaren R, Lat I, Erstad BL, Bartlett B, et al. Pharmacoepidemiology of stress ulcer prophylaxis in the United States and Canada. J Crit Care [Internet]. 2014;29(6):955-60. Available from: http://dx.doi.org/10.1016/j.jcrc.2014.06.025

18. Yilmaz Ş, Bayan K, Tüzün Y, Dursun M, Canoruç F. A head to head comparison of oral vs intravenous omeprazole for patients with bleeding peptic ulcers with a clean base, flat spots and adherent clots. World J Gastroenterol. 2006;12(48):7837-43.

19. Katzung BG, Masters SB, Trevor AJ. Special Topics. In: Basic and Clinical Pharmacology. 12th ed. Mc Graw Hill; 2012. p. 1081-114.

20. Clark K, Lam LT, Gibson S, Currow D. The effect of ranitidine versus proton pump inhibitors on gastric secretions: A meta-analysis of randomised control trials. Anaesthesia. 2009;64(6):652-7.

21. Zeitoun A. Stress ulcer prophylaxis guidelines: Are they being implemented in Lebanese health care centers? World J Gastrointest Pharmacol Ther. 2011;2(4):27.

22. Armstrong TA, Coursin DB, Devlin J, Duke JS, Fish D, Edgar R, et al. Stress ulcer prophylaxis ASHP Report ASHP Therapeutic Guidelines on Stress Ulcer. In Am J Health-Syst Pharm; 1999. p. 347-79. 